\title{
The Materiality of Pentecostal Religious Healing: The Case of Cameroonian Migrants in Cape Town
}

\section{Henrietta M. Nyamnjoh}

\begin{abstract}
Based on ethnographic research among Cameroonian migrants living in Cape Town, South Africa, this study looks at the use of sacred healing objects among these migrant groups. Exploring the extent to which migrants' everyday lives are rooted in the nexus of attaining divine healing and consolidating healing gains through the use of religious sacred healing objects and the 'word', I interrogate how the use of these objects within Pentecostal churches fulfils the quest for divine healing among Cameroonian migrants. I argue that the sheer challenges of migration and the difficulties that goes with it, increases the tendency of migrants to look towards Pentecostal churches for healing, increases, so too does their belief in the healing powers of various healing objects that migrants buy in a bid to attain wholeness and be at peace with oneself.
\end{abstract}

Keywords: Religious healing, sacred objects, Pentecostal churches, Cameroon, migration

\section{Introduction}

This one, it is golden oil that Pastor Bushiri brings from Israel. He gives it in a small box to international visitors. I have it, see ... this stuff, they do help me ... with a sticker. You buy the sticker, the book and anointing oil. Then they will give 
you water for free. When I spray the water I feel different. I'm feeling better since I've started spraying. This is the fourth one. This one, I bought it again last time from our own church. Even that of T.B. Joshua, I got a lot. Each time people travel from here to Nigeria to the synagogue I give them money to buy for me anointing oil, holy water and stickers and that one comes with a free DVD (Zora, 29/06/2017).

In this paper, I use the story of Zora - a widow in her mid-forties who came to Cape Town in 2011 and is involved in informal trading - and those of other migrants to illustrate the extent to which migrants actively seek religious healing through the use of sacred objects. I explore the everyday practices of attaining healing and encounters with objects of healing and how migrants make meaning of lived religion to provide solutions to their challenges. Zora had a swollen leg and foot rot, which she believed was caused by a python living in her body. Zora did not go to the hospital to diagnose the foot rot, but rather used holy water and anointed oil to apply to the affected area, as well as anointed stickers to protect her from future illnesses. Zora's story epitomises that of other migrants for whom the use of various religious healing objects corresponds to that sought from traditional healers. Pentecostal churches have replaced traditional healers by inculcating African cultural beliefs and cosmologies in their healing practices, and offer remedies that are adaptations of traditional practices. While recognising the similarities of their healing practices, their sources are different. This is pointed out by Allan Anderson (2001:106):

The diviner has traditional answers to these questions, which invariably involve the performance of a ritual act aimed at placating an offended ancestor. In keeping with the holistic worldview, the whole of the African environment is given religious meaning .... African prophets, provide an ostensibly biblical solution to the questions relating to tangible physical needs and the persistence of affliction.

One such solution is the healing and deliverance offered by Pentecostals that fulfils a felt need and therefore produces a 'product' that is attractive in 
Africa's religious market (Anderson 2006). Globalisation has opened up the world to accelerated flows of people, goods and services. However, in the face of such accelerated mobilities has emerged the globalisation of Pentecostalism as an export to the rest of the world. As Corten and Marshall-Fratini (see also Droogers 2001) argue, the reason for such exponential growth is Pentecostal capacity to embody the,

open-endedness of a global network of flows, a composite of heterogeneous elements flexible and indeterminate enough in meaning to allow their setting to work in multitude of contexts, yet offering at the same time a stable collection of narrative formulae and well-organised structures which provide a solid anchorage for individuals at large in the frightening sea of possibilities and frustrations (2001:3).

Along with this export is the mobility of sacred healing objects that are sought after and believed to have healing effects. Migration does not always fulfil migrants' expectations in terms of upward social mobility. This, in combination with the everyday challenges of living as migrants, has resulted in the search for alternative possibilities that go beyond local cultural repertoires (Corten \& Marshall-Fratani 2001). The fear and excitement born of social dislocation and the desire for new communities coincide with needs for physical healing. For migrants in particular, Pentecostal religion opens up new avenues of possibility and serves to soothe their frustrations, challenges and unfulfilled fantasies. As Ferguson (2006) and Nyamnjoh (2004) explain, Pentecostalism thus offers that opening up to the world that globalisation had promised for some, yet did not deliver. The influence of Pentecostal evangelism with its focus on doctrines such as miracle healing, salvation and the prosperity gospel speak to individuals, and especially migrants, bedevilled by the challenges of migration. Moreover, these doctrines also espouse a cultural context of witchcraft as some of the causes of their problems, which attract migrants who identify with such evangelism.

Amanda Porterfield (2005:174) states that Pentecostalism resonates with experiences of healing associated with indigenous cultures, while at the same time promoting a code that enables migrants to reorganize their lives and cope with the challenges, disease, loneliness, and stresses of urban life. Pentecostalism helps newcomers find themselves among the high paced and 
brutal realities of multinational cultures and economies of city life. It also gives people a new chance at establishing themselves and a means of forging new ties of interpersonal and institutional support. In this respect, healing is very much at the centre of what people need and want from religion as it provides a framework for making sense of the world and coping with life (Musgrave, Allen \& Allen 2002). While the search for healing is synonymous with cultural forms of healing where those afflicted consult traditional healers who diagnose the cause of the illness and prescribe herbs and a process of ritual cleansing, Pentecostalism provides alternative healing practices that take similar African worldviews seriously, such as the belief that evil spirits are the causes of ill health. From this perspective, Pentecostals invoke the power of Jesus as the divine healer and make use of sacred objects styled after those previously sought from traditional healers as alternative forms of healing as well as providing a cultural community that substitutes the dominant culture in significant ways (Droogers 2001; Onyinah 2006; Kalu 2008; Gornik 2011; Omenyo 2011).

Academic research on Pentecostal healing is extensive, illustrated by the numerous articles that have addressed various aspects of Pentecostalism. However, these studies have paid inadequate attention to the materials and objects that play a part in healing. Sacred objects produced by Pentecostal churches (PC) are very much in demand and churches have placed a high premium on them. By the same token, migrants have added value to these sacred objects by the high demand and healing values placed on these goods. Consequently, these goods are increasingly transnationally mobile and sought after by those in need of healing. This paper explores the various uses of sacred objects for healing by migrants as well as migrants' beliefs about the effectiveness of such objects. Focusing on Cameroonian migrants in Cape Town, I look at the different objects that they buy from PCs. These objects include holy water, anointing oil (olive oil), wall/car stickers, wrist bangle, DVDs containing prayers as well as manuals on how to use the healing objects. In addition, there are equally intangible objects that have proven useful, especially for those unable to regularly purchase the objects. These include invoking the 'blood of Jesus' and one's ability to be 'soaked in the word'. All of which are referred to by David Oyedepo of Winner's Chapel as 'Biblical power instruments' (Oyedepo 2006, cited by Gifford 2011:254). Quite often, Christians are expected to use a combination of tangible and intangible materials to achieve effective and victorious healing. Using this form of 
healing therefore is inspired by Jesus' empowerment to all of his followers to pray, heal, and trust God for miracles, just as Jesus himself had done. Paul Alexander also notes that the belief in the healing power of such objects follows instructions that Jesus gave before returning to His Father: 'if you are sick, ask the mature believers to come and pray for you. Ask them to put olive oil on you in the name of the Lord. Prayers offered in faith will make sick people well' (2009:6; see also Kalu 2008:264). The paper asks how and to what extent migrants have adopted sacred religious objects to attain healing.

This study draws on ethnographic observations and in-depth interviews conducted between 2016 and 2017 in Cape Town, South Africa. A total of 18 migrants (12 women and 6 men) were interviewed. Some of the informants were interviewed repeatedly, especially those who were regular buyers of healing objects from different churches. The aim of repeated interviews with this group of informants was to ascertain their beliefs about the effectiveness and motivation for using multiples healing objects simultaneously.

Migration from Cameroon into South Africa started after the demise of apartheid in 1995. Between the late 1990s and early 2000 South Africa was considered as an alternative to route into Europe, following the tightening of Europe's border. From the mid-2000s, South Africa became the destination of choice for many. For most migrants, however, South Africa was still considered as a springboard to onwards migration; a process which eventually stalled when migrants realized the impossibility of securing a visa due to being undocumented. Faced with the reality of life in South Africa being different from the utopian ideas held, coupled with the challenges of settling in in the margins of society and financial expectations from families back home, the health of many migrants has been affected (Nyamnjoh 2017). The corollary to this is the feeling of perceived witchcraft (attributing illness because of witchcraft by relatives at home), psycho-social illness, physical, spiritual, and emotional ill health. While some resort to conventional health seeking behaviours, others resort to PCs for healing. For the latter, categorisation of most of their woes as spiritual inhibits them from going to the hospital to seek biomedical healing. Rather, they approach PCs for divine healing and prophesy to unearth the root causes of their ill health. As Andrew Chestnut intimates, having reached a point of despair at the 'closed door' the afflicted listen to the Pentecostal proselytizers who offer an immediate and comprehensive solution to the suffers' physical, psychological, social or spiritual illnesses (1997:172). In the process, migrants are inducted into the healing powers of 'Biblical power 
instruments' to attain total healing and wholeness.

This study draws on literature at the migration-precarity-agency nexus (Paret \& Gleeson 2016). In addition to this, I add a fourth connection - religion - to understand what makes migrants' lives precarious, and the ways in which they redress the precariousness. It is in this regard that I leverage the migrationprecarity-religion-agency intersections to understand migrants' health challenges in the host country, and the agency that drives health-seeking ways. Inasmuch as migrant existence is often precarious in multiple, and reinforcing, ways, the three dimensions without religion has been used to mainly to comprehend structural inequalities and labour related marginalisation. The addition of religion to the above nexus foregrounds the fact that religious migrants can be agentic even when faced with challenges or operating within oppressive institutional contexts.

Religious multi-sitedness provides reasons for migrants' going to different churches to seek answers, meaning and expression across multiple social institutions (Ammerman 2010). Following Paret and Gleeson (2016: 280) the central 'significance of the precarity concept lies in the way in which the concept connects the micro and the macro, situating experiences of insecurity and vulnerability within historically and geographically specific contexts'. Migrants' experiences, from the vantage point of sickness, psychosocial trauma and perceived witchcraft (attributing illness to witchcraft by relatives at home), in the host country therefore provide a crucial window into another form of precarity. Conversely, the notion of precarity provides a beacon of hope for overcoming passiveness because it represents a possible reference point to actively seek life-changing solutions (Waite 2009). It is this meaning-making and seeking of solutions, referred to by Neilson and Rossiter (2008) as 'translation', that reflects agency among migrants. While Paret and Gleeson (2016:282) identify four forms of agency, this study will be limited to one form- 'individual agency' - which migrants use to both understand and address their illness.

\section{Biblical Pathways to Divine Healing}

Facing illness, psychosocial trauma or spiritual attacks that magnify the fragility of existence can lead migrants to question the purpose of life. Divine healing and the sense that life has meaning can provide them with the opportunity to develop a personal symbolic visualization of and closeness to a 
higher power. Through prayers and church attendance, as well as the use of healing objects migrants can reify their faith in God. As Musgrave, Allen and Allen (2002) and Wuthnow and Offutt (2008) show, reaching out to attain total healing involves spiritual practices and encounters with various religious objects and information, including audio/video recordings and books/ pamphlets. Healing can include the laying on of hands and the anointing with oil. The healing offered to people relies upon various symbols, especially the sprinkling of holy water, which is a sacrament providing ritual purification and protection. In this regard, Popoviciu, Popoviciu, Birle, Olah, and Negrut (2013) note that the way religion interprets, theorizes, and responds to illness plays an important role in how that illness is understood, and also determines how persons affected by various ailments are (mis)treated in a given context. It is for this reason that migrants actively purchase and rely on religion and healing objects, they place trust in their efficacy and what they offer in terms of healing and protection against marginality (McCullough \& Larson 1999). Symbolic healing practices are justified by the Bible, where Jesus used mud and spittle to heal a blind person, Peter used cloths to heal, and Old Testament prophets used staffs, water, and various other objects to perform healing and miracles (Anderson 2002). Such practices have ancient roots within the Christian tradition. In the Old Testament, olive oil, mixed with various spices, was used in anointing priests and kings. During the early Middle Ages this became the sacrament of Extreme Unction, which was administered as a last rite in the Roman Catholic Church. Since Vatican II, however, it has been restored as a sacrament of healing, and is in wide use in PCs. They signify and seal God's power and gifts that the church uses in healing: forgiveness, reconciliation, hope, and love. They remind us that Christ has given of himself for all of creation (Evans 1995).

Similarly to the use of these objects, the belief in the 'word' or one's ability to be 'soaked in the word' is a fundamental way of attaining healing. Having one's life directed in a meaningful way was the essence of spirituality for many of the respondents in this project. Pentecostal hermeneutics thus 'underscore the emphasis on the power of the word in spiritual formation; the word resists forces that could lead one to backslide, reverses curses and provides deliverance' (Kalu 2008:269). My informants confirmed that they get healing through the 'words of knowledge' (liturgy), sacred objects such as, anointing (olive) oils, holy water, handkerchiefs, and anointed wall/car stickers (see also Lartey 1986). 


\section{Sacred Objects/ Biblical Power Instruments and their Healing Powers}

The following excerpt from my interview with Sam captures the mobility and healing powers of sacred objects;

Prior to Pastor John's ${ }^{l}$ coming to Cape Town for a three day crusade, he shipped cartons of anointing oil, holy water handkerchief, wrist band and stickers, and his autobiography which will be sold during the crusade and thereafter as a package. Here is some in my car [showing the researcher], I always have some in the car. I never go out without anointing oil and holy water. In the event that I have to drive out of town, I always spray holy water on my tyres and anoint myself with the oil. This is to protect me and ensure a safe journey. Most especially, when I am going to a place that I am not sure of the people I will be meeting, I simply carry both on me after first anointing myself before coming out of the car for my protection (Sam, 01/05/2017).

Sam came to South Africa in 2000, and found a job in the film industry. In 2006 he decided to return to Cameroon and set up his own business, which was unsuccessful. Two years later he returned to South Africa unemployed and with a broken spirit. After a lengthy interview with Sam, and as I walked him to his car, a phone call came in asking whether he still had anointing oil for sale, to which he responded in the affirmative and arranged to supply the prospective buyer after we separated. I was curious to know more and a conversation ensued as to how he came to be the contact person for people in Cape Town, Johannesburg and Pretoria wanting to buy the healing products. He then went on to tell me how it was an important aspect of his spirituality. Drawing on his narrative, these objects are used for healing as well as for protection to evade ill health and to ensure permanent health.

Jacques Matthey (2004:408) notes that to 'experience healing is not just to experience freedom from sickness and illness, or problems and suffering'. Healing is a sign of what the Old Testament calls 'Shalom' (peace, salvation) as the establishment or restoration of right and reconciled relationships, now and at the end of time'. From this perspective, Sam's use of

${ }^{1}$ Pastor John came from Cameroon at the invitation of Sam in February 2017. 
anointing oil and holy water is to ensure good health and protect against anything that may cause ill health. Significantly, the use of these objects is reassuring, and gives him a feeling of peace, of God's grace being with him and protecting him in his encounters. Sam's actions equally point to the dynamism of healing. As intimated by Matthey (2004:408) healing is not simply to 'experience freedom from sickness or problems and suffering', healing includes a 'state of wellbeing of the individual; of physical, mental, spiritual, economic and social wellbeing in harmony with each other'. Sam's experience also underscores the influential teachings of PCs regarding the power of anointing; 'the empowering presence of God that makes things happen ... "anointing" is the power of God in action' (Asamoah-Gyadu 2005:22). While anointing may simply be the laying of hands over a Christian seeking healing, it also involves various religious materials that are believed to possess healing powers to connect the sick to God.

Like Sam, Cathy believes in the power of anointing oil and holy water, and believes they are a 'must have' in the car and be used when embarking on a long drive or meeting unknown persons. The holy water and anointing oil that Cathy has in her car are considered prized gifts because they were given to her by Pastor John after she worked as an usher during a crusade in Cape Town. As such, the holy water and anointing oil have double anointing powers given that the pastors prayers are perceived as more powerful than those of a simple church member (Währisch-Oblau 2001; Asamoah-Gyadu 2005). When she enters her car, she sprays some holy water on the car and on herself. This is to remove any bad spirits that may enter into her car and keep her car 'immune to accidents and scratches' (Oyedepo, cited in Gifford 2011:259). Although she is a nurse, Cathy's medication of choice is anointing oil and holy water. Narrating her experience regarding experiencing a painful leg, she explains that:

I woke up one morning with excruciating pain on my right leg, deep inside my leg. I thought many things. I thought again, maybe it's the evil spirits that has been stopping my friend from getting a job that has attacked me now for trying to help her, but I said no, I'm not going to go to the doctor because I know if I go they're going to say, oh you have a blood clot, oh you have this, nerve pinched or you have that. I know all these things, I'm a professional nurse, but I'm not going to go to the doctor. I took the bottle of anointing oil and holy water that 
Pastor John gave to us as ushers during the crusade, prayed over it again and rubbed and sprayed on the leg. Although the pain did not go completely, I was relieved of that excruciating pain (Cathy, 27/04/2017).

Despite being a nurse, Cathy avoids biomedical treatment because 'its use is viewed as evidence of "weak" faith' (Anderson 2002:526). In particular, Cathy believes her object have a special potency as they were given to her by the pastor. The efficacy of these objects has been expounded by Bishop David Oyedepo who maintains that the oil will 'give a man or any object on which it is poured immunity against any form of evil...It is an all-purpose drug for any ailment of life' (Oyedepo 2006, cited in Gifford 2011:254). Cathy is happy with the partial healing she received and draws strength from the fact that the excruciating pain disappeared and she could at least walk. Her thinking is corroborated by Onyinah (2006:125-126, see also Kalu 2008) who posits that God chooses how and when he wants to act in response to people's pleas for healing. To the informants in this study, the healing powers of sacred objects are considered as panacea for any ailment, even spiritual attacks and difficulties in navigating the everyday life.

\section{Zora's Story}

Zora is a widow in her mid-forties, who has three children living in Cameroon with her mother-in law. She came to Cape Town in 2011 and is involved in informal trading. When meeting her for an interview, she was quick to show me a section of her closet that is packed full with bottles (some of which were empty) of anointing oil, holy water, wall stickers, DVDs and other memorabilia she has bought. Her attendance at crusades is propelled by the fact that she has a big problem - she believes there is a python living inside her body that has led her right leg to swell and caused foot rot. The use of the oils and water is to quell the movement of the python in her body, as well as to treat the foot rot. In particular, she considers holy water as ritual purification and protection from further evil spirits. The oil is used to rub on her stomach and leg. On other occasions, she sprays the handkerchief with holy water and oil and wraps it around her leg when it is painful.

She explained her problem and narrated to me how she has been buying the various sacred objects: 
I was having big problem. I was physically feeling a snake is moving in my body, even in my stomach. I feel movement all over me, even my toes, when I sit it's like a python all over inside me. It was so serious, I went to other churches, when I hear that a pastor is coming in Johannesburg I go as international visitor ${ }^{2}$. You see, this problem of python is something which is like a strong spirit in the family, which to deliver is not an easy problem... That particular python is affecting my leg, you can see here [shows the interviewer her swollen leg], it was sore, it's getting rotten. They are very helpful, but that from Synagogue in Nigeria has more anointing. Last week I was limping due to pains I felt on this side [points to her waist down to her left leg], So, I just decided, last Friday I went to this guy [Sam], to buy water from Pastor John just to spray on my leg because I didn't have much left. I don't believe in hospital! If I have a problem, I just depend on this stuff. This stuff, they do help me, the water is important. Since I've started spraying, when I spray it, I feel different. I'm feeling better (Zora, 29/06/2017).

In addition to the holy water, Zora uses stickers for protection. She explained that:

This sticker when I go anywhere I put it like this (stuffs it in her bra), I don't put it by the door. Because when I put it by the door, for me, I'm wasting it. I put it on myself, especially when I am going somewhere I consider dangerous. When I put like this (stuffed in her bra), whatever stress or I'm thinking a lot about something, in the end I will succeed. Me! I believe in their anointing power and it happens! (Zora, 29/06/2017).

The powers attributed to the various objects are enormous and Zora's belief is driven by the faith that she has in the objects. Anointing oil and stickers, have proven their potency to her and she can testify to the 'empowering presence of

2 There is an advantage of going as international visitor coming from Cape Town because she pays more and has priority of front row seat and will meet the pastor. 
God' that makes things happen. The oil as a substance is a transmitter of invisible grace (Asamoah-Gyadu 2005:22). While the anointing is usually obtained by applying the oil accompanied by the touch of the pastor, selfanointing is also common. Those engaged in self-anointing are still able to testify the power of God in action, as seen in the stories told by Zora and Cathy. Migrants believe the objects help them maintain a constant relationship with God, and therefore make all things possible for them.

Inasmuch as Zora is able to buy locally and from crusades, she depends on those traveling to Nigeria to buy sacred objects from Prophet T.B. Joshua's Synagogue Church of All Nations (SCOAN). She regularly sends money through those who travel to Lagos for healing to buy a package comprising holy water, anointing oil, DVDs and a prayer manual. When Faith travelled to SCOAN to seek healing for the lump in her breast, she returned with anointed oil/stickers and holy water and a wrist band. Navigating everyday life for Zora equally requires that she carries a sticker on her person to block anything that impedes her functioning in her daily life. To this effect, she tells me a story about an incident on a train and about how she did not have enough transport money to get home, but because she had the sticker on her, God heard her worries and put someone on her path to give her a train ticket to last for three days. For her, this is a sign of answered prayers. She surmises that, 'You see! Because I was having my sticker with me, so God listened!' The result of going out with her sticker on her and having a silent request to God proves her point about the effectiveness of the sticker to provide solution to her problem.

The benefits of these religious materials outweigh any price tag placed on them. Hence, migrants have come to rely on them as sacred and protective ammunitions that mediate between them and God. Whereas Asamoah-Gyadu (2004:373) cautions whether anointing with oil works, these healing practices must not be 'absolutized' and divorced from other therapeutic methods; those who rely on them for healing believe the effects seem absolute. Zora rationalises the healing of her leg through the use of anointing oil and holy water that she regularly sprays on the affected area, while Cathy believes staying free from accidents is due to the oil that she rubs on her tyres.

For many migrants, crusades are occasions that are perceived to be filled with healing. Zora considers crusades as her best shows because they are filled with anointing. She states that crusades, especially those pastors filled with prophecy and anointing, is where divine healing is often sought. Her problem is the swelling of her leg/foot rot. She stated that 'at times there are 
some crusades when I go I feel like someone is taking out shoes from my leg, I feel many things'. Although these crusades are held in Pretoria or Johannesburg with guests expected from neighbouring countries, Zora prefers to attend the crusades as an international guest because of the advantages it includes. International guests pay R5000 (approximately USD384), which includes lodging, meal, and transport to and from the crusade venues. In addition, international visitors are provided with badges that allow them access to reserved front row seats, attend a diplomatic service (a service only for those who paid R5000), and have a one-on-one meeting with the pastor for anointing and are given sacred healing materials. Zora has a lot of experience attending crusades and has travelled to many. She narrates her healing experience with Prophet Omoto Fufeyin:

Before I went to the crusade this my leg was swelling, this particular leg [shows the researcher her right leg] was swelling. Then the day I went, as I was in that crusade, when the pastor passed next to me, it was like a pressure was going out of my leg. That my foot, it was like they are taking out somethings, they are pinching, it was like a serious pressure was being released until I come back, and then my foot got better. It stayed well for quite some time, but when I dreamt that I wore a pair of socks in the night, I woke up and the swelling returned, along with signs of foot rot (Zora, 29/06/2017).

Zora's visits to crusades highlights the fact that healing could be 'gradual' or 'natural', but more importantly, that God sometimes chooses not to heal, and that suffering is part of the divine economy (Warrington 2003). It also shows how Pentecostal preachers and their followers have put a premium on divine healing (Kalu 2008). In order for this premium to be acceptable, the church, it seems, has packaged the product (diplomatic service), such that Christians see its essence as a product filled with 'instant' healing. The reception given to the paying guests reinforced the significance of the premium. Importantly, the language used - international diplomatic service - to address the guests has been politicised to make them feel truly international. International guests receive significant attention and are the ones to be shown on TV regularly. Zora was very proud that on her return to Cape Town, lots of people reported that they saw her on TV. 


\section{Healing and Impartation through the 'Words of Knowledge'}

The 'word', like healing objects, is a powerful tool to attaining healing. Most informants argued that the word gives them a foundation from which they can more easily move into the other levels of healing. Sahkti Gawain (1997:15) surmises that "without the ability to make this inner spiritual connection, it may be very difficult or even impossible to find the inspiration, understanding, and strength they need to confront the difficulties and challenges of healing the other levels'. Through the word, Pentecostals declare a message that reclaimed the biblical traditions of healing and protection from evil (Anderson 2002). The word thus could be likened to that of Jesus to His disciples during the Sermon on the Mount. If they heard His words and put them into practice, they would be able to withstand any storm. Similarly, when migrants listen to the words and obey them, they hope to build their lives on a steady and solid foundation. Healing through the word therefore requires one to have an understanding of what the Bible teaches, to live according to the teachings, to pray and be prayed for. On the effectiveness of the word Grace noted that; 'what I like about the healing ministry is that they teach you the word of God about healing so that you understand it's not magic, it's a process and it's what the word of God says'. It is through the word that believers seek to understand their problems and get healing. Given that preaching the word and divine healing are inextricably linked, surrendering to the word is an acknowledgement that the full gospel contains good news for all of life's problems. As Brueggemann (1993:88) articulates 'the word is embodied in the community and, therefore, the text is read eschatologically as the intrusion of the kingdom of God into the present and as empowerment in living out its promises'. Quite often, the theology of these churches consists of a clear and direct message that addresses the concerns of Christians, particularly those of migrants, in ways that are convincing to them (Asamoah-Gyadu 2005). Importantly, listening to the word in a familiar language (such as Pidgin English, or English with a recognisable accent), makes homiletics accessible and affirms peoples' experiences to the extent that it is applicable to their lives. It is common that Pentecostal Christians come to church with big notebooks to write down the teachings that they will spend the rest of the week meditating on and apply to their daily lives. Many preachers also encourage congregants to write down and underline sections of particular teachings.

This teaching seems to be what Cathy needs. Recalling her earlier troubled life with relationships leading to emotional instability, it would appear 
her emotional problems are still on-going; this time troubled by happenings within her family and she is unable to understand why she is still celibate. As the third child in a family of ten siblings, the burden of assisting the family rests on her. Cathy cannot fathom why she has to be the only one looking after the family, and it weighs her down. She explains her worries,

Growing up as a child, I really respected all these laws of the church and I thought that my life will be easier as an adult. But why must I struggle like this in my life? I am left with two children, I'm alone in my life. My parents didn't have a good job, but I'm the only one to lift up my whole family... I have to spread all my resources that I've gained in my whole life...I was stressing in all these things. Why is it that other people can get scholarships but I have to pay for everything from my pocket? Why it is that people are settled? Married? I am not. Why is it that I had to leave Cameroon to come to a man and be disappointed in this kind of a way? Then I look, I see my children, what can I do? How can I prepare my children? So, all of these things were disturbing a lot and when I went to church and they would preach and they would emphasise that God is the superior, there is no human being that can do anything to you. That consoled me. Now I look back and I say oh my God, even if I had all the money in my account and my sisters, maybe, had died what will I do with all those things. So, that helped me, to be happy. I used to be depressed a lot, but after listening and getting the word, soaked in the bible and the preaching analysed, things became clearer and I started thinking positive (Cathy, 27/04/2017).

Cathy's self-interrogation is suggestive of a emotional/psychological response to marginalisation and the challenges and demands from family in the home country, experienced by many migrants. It illustrates the precarity of being a migrant - often a life of double challenges - navigating the daily life and demands from family in the home country. In a way, divine healing is achieved by practicing love and the need to lay down her life for others. Similar to the woman with haemorrhage in the bible, Cathy stepped forth in faith and grasped God's standing offer of emotional stability. The word thus provides 'an asylum of therapeutic assistance' (Eugene 1995:66), as well as a place of shelter. Her discernment of biblical scripture seems to have empowered and given her agen- 
cy to see her responsibility towards her family not so much as a burden but an act of love and kindness. Consequently, she has the simple human desire to have more control and power over her life and circumstances (Alexander 2009).

Understanding and applying the words of knowledge in one's daily life is a prerequisite to attaining healing. This is highlighted by Anita's story. Anita is a student that also works as a waitress. She states that seeking help from Bishop Elijah has helped her with anger management. A particular sermon seemed to have been destined for her - 'This is for me', 'he is talking to me' she said when the pastor was preaching. According to Anita, she had a problem with anger management and wanted healing from this 'monster' that had taken hold of and made her unable to smile. To her, her life was miserable, and having been to church a couple of times, she felt she could turn to the Bishop Elijah for help. She elaborated:

When I came in South Africa, I was that person with so much anger in me. I was not the person who could smile...bearing grudges with people. But everyone around me look happy, I felt I needed help. That's when I went to see papa (Bishop) ... when I came to church, I got healing from the 'word'. Bishop told me that the things that will help me are to forgive and to love. He teaches how to forgive because when you forgive you will also be forgiven. When you don't forgive it's like you are walking with dirty things, rotten stuff in your head... But when they teach you about forgiving people who hurt you, to start by knowing how to love them, then you'll start to love yourself. Then you see the smile...Now I'm a person that makes so many jokes. At my work place I talk too much. I make jokes. I feel so happy with myself now (Anita, 21/05/2016).

Anita believes that for healing to come, she has to apply the words of knowledge that she has received, which will free her from present emotional and physical problems by learning forgiveness; the gospel is a potent remedy for her affliction.

\section{Conclusion}

Migration and settling in a new country is fraught with challenges, and too often causes a strain on migrants' lives, Hence, many migrants turn to religion 
for solace and healing. Divine healing is about how people face the paradox of illness and wellness, tragedy and triumph, despair and hope, pain and joy that are always shifting and changing (Stoltzfus \& Green 2013). Facing an ongoing illness that highlights the fragility of the human experience therefore provides a connection to the exploration of divine healing through various means. Therefore, when seeing precarity - illness, vulnerability, exclusion, challenges and marginalisation - as opportunities for migrants to cultivate closeness to God, spiritual cultivation and healing become important. Healing goes beyond physical cure or psycho-physical health, but extends to attaining a sense of complete wellbeing and wholeness - 'whole in mind, body, spirit and relational dynamics' (Stoltzfus \& Green 2013:291). The attribution of healing to sacred religious objects has seen migrants investing in their purchase from different churches to alleviate their plights. Unlike voodoo practitioners who use the occult arts formulas as magic, powders, potions, and other ammunitions to heal (Payne-Jackson 2008), Pentecostals follow biblical scriptures of the Old/New testament's uses of anointing oil, salt and water, books/stickers, cloths (liken to that used to wipe Jesus' face by Veronica) and words of knowledge for healing. The challenges of migration and the various forms of exclusion in society have not only resulted in migrants turning to religion for refuge, but has equally led to the increased use of sacred objects whose anointing powers are perceived to break the 'yoke' of people and allow them to push back against their precarity. The use of these objects has challenged traditional beliefs and use of amulets, with the call for Christians to turn to God for the ultimate amulet that heals and protects them from all ailments. This in a way is migrants' ideational discourses against precarity through individual actions (Paret \& Gleeson 2016:288) and the purchase and use sacred objects presumed to provide solace in their everyday lives.

While various bodily ailments provoke strong emotions, migrants' deployment of and encounters with objects of healing, also opens the door to a new form of awareness and healing. Such awareness can be the 'interventionist' purpose of the objects (Asamoah-Gyadu 2005), as they are used to seek alternative solutions and understandings of illness and to incorporate divine insight, practice, and self-understanding to bring solutions to problems or healing. In this regard, one of the most influential ways PCs keep their followers, especially those affected by migration, is through the transnational flow of religious materials and goods that are considered to have talismanic powers. 


\section{Funding acknowledgement}

The research project this article draws from was funded by the African Humanities Program Postdoctoral Fellowship of the American Council of Learned Societies (AHP).

\section{References}

Alexander, P. 2009. Signs and Wonders: Why Pentecostalism is the World's Fastest-Growing Faith. San Francisco: Jossey-Bass Publications.

https://www.amazon.com/Signs-Wonders-Pentecostalism-Fastest-

Growing/dp/0470183969

Ammerman, T.N. 2010. The Challenges of Pluralism: Locating Religion in a World of Diversity. Social Compass 57, 2:154 - 167.

https://doi.org/10.1177/0037768610362406

Anderson, A. 2001. Stretching the Definitions? Pneumatology and 'Syncretism' in African Pentecostalism. Journal of Pentecostal Theology 10,1:98 - 119 .

https://doi.org/10.1177/096673690101000106

Anderson, A. 2002. Pentecostal Approaches to Faith and Healing. International Review of Mission XCI: 363:523 - 534.

https://doi.org/10.1111/j.1758-6631.2002.tb00365.x

Anderson, A. 2006. Exorcism and Conversion to African Pentecostalism. Exchange 35,1:116 - 133 .

https://doi.org/10.1163/157254306776066960

Asamoah-Gyadu, K. 2004. Faith, Healing and Mission: Reflections on a Consultative Process. International Review of Mission 93, 370/371:372 378.

https://doi.org/10.1111/j.1758-6631.2004.tb00466.x

Asamoah-Gyadu, K. 2005. Anointing through the Screen: Neo-Pentecostalism and Televised Christianity in Ghana. Studies in World Christianity 11, 1:9 $-28$.

https://doi.org/10.3366/swc.2005.11.1.9

Brueggemann, W. 1993. Texts under Negotiation: The Bible and Postmodern Imagination. Minneapolis: Fortress.

https://www.amazon.com/Texts-Under-Negotiation-Postmodern$\underline{\text { Imagination/dp/0800627369 }}$ 
Chestnut, A. 1997. Born again in Brazil: The Pentecostal Boom and the Pathogens of Poverty. New Brunswick,NJ: Rutgers University Press. https://www.amazon.com/Born-Again-Brazil-PentecostalPathogens/dp/0813524067

Corten, A. \& R. Marshall-Fratini 2001. Introduction. In Corten, A. \& R. Marshall-Fratini (eds.): Between Babel and Pentecost: Transnational Pentecostalism in Africa and Latin America. London and Bloomington: Hurst Publishers and Indiana University Press.

https://www.amazon.com/Between-Babel-Pentecost-TransnationalPentecostalism/dp/0253213789

Droogers, A. 2001. Globalisation and Pentecostal Success. In Corten, A. \& R. Marshall-Fratini (eds.): Between Babel and Pentecost: Transnational Pentecostalism in Africa and Latin America. London and Bloomington: Hurst Publishers and Indiana University Press.

https://www.amazon.com/Between-Babel-Pentecost-Transnational-

Pentecostalism/dp/0253213789

Eugene, M. T. 1995. There is a Balm in Gilead: Black Women and the Black

Church as Agents of a Therapeutic Community. Women Therapy 16, 23:55 - 71 .

https://doi.org/10.1300/J015v16n02 08

Evans, A. R. 1995. The Church as an Institution of Health: Making it Happen. Interpretation 49, 2:158 - 171.

https://doi.org/10.1177/002096439504900205

Ferguson, J. 2006. Global Shadows: Africa in the Neoliberal World Order.

Durham \& London: Duke University Press.

https://doi.org/10.1215/9780822387640

Gawain, S. 1997. The Four Levels of Healing: A Guide to Balancing the Spiritual, Mental, Emotional, and Physical Aspects of Life. Novato, CA:

Nataraj Publishing.

https://www.amazon.com/Four-Levels-Healing-Balancing-

Spiritual/dp/1577310993

Gifford, P. 2011. Healing in African Pentecostalism: Victorious Living of David Oyedepo. In Brown, G.C. (eds.): Global Pentecostal and Charismatic Healing. Oxford: Oxford University Press. https://doi.org/10.1093/acprof:oso/9780195393408.003.0013

Gornik, R.M. 2011. World made Global: Stories of African Christianity in New York City. Michigan: Wm. B. Eerdmans Publishing Co. 
https://www.amazon.com/Word-Made-Global-Stories-

Christianity/dp/0802864481

Kalu, O. 2008. African Pentecostalism: An Introduction. Oxford: Oxford University Press.

https://doi.org/10.1093/acprof:oso/9780195340006.001.0001

Lartey, E. 1986. Healing: Tradition and Pentecostalism in Africa Today. International Review of Mission 75,297:75 - 81.

https://doi.org/10.1111/j.1758-6631.1986.tb01455.x

Matthey, J. 2004. Faith, Healing and Missions. International Review of Missions 93, 370-371:407 - 412.

https://doi.org/10.1111/j.1758-6631.2004.tb00469.x

McCullough, M. E. \& B.D. Larson 1999. Religion and Depression: A Review of the Literature. Twin Research 2, 2:126 - 136.

https://doi.org/10.1375/twin.2.2.126

https://doi.org/10.1375/136905299320565997

Musgrave, F.C., C.E. Allen \& G.J. Allen 2002. Spirituality and Health for

Women of Color. American Journal of Public Health 92,4:557 - 560.

https://doi.org/10.2105/AJPH.92.4.557

Neilson, B. \& N. Rossiter 2008. Precarity as a Political Concept, Or, Fordism as Exception. Theory, Culture \& Society 25, 7-8:51 - 72.

Nyamnjoh, F.B. 2004. Globalisation, Boundaries and Livelihoods:

Perspectives on Africa. Identity, Culture and Politics 5, 1 \& 2:37 - 59.

Nyamnjoh, H.M. 2017. Navigating 'ngunda'/ 'adoro' and Negotiating Economic Uncertainty amongst Mobile Cameroonian Migrants in Cape Town (South Africa). Critical African Studies 9, 2:241 - 260.

https://doi.org/10.1080/21681392.2017.1340846

Omenyo, C. 2011. New Wine in an Old Wine Bottle? Charismatic Healing in the Mainline Churches in Ghana. In Brown, D. (eds.): Global Pentecostal and Charismatic Healing. Oxford: Oxford University Press.

https://www.amazon.com/Global-Pentecostal-Charismatic-Healing-

Gunther-ebook/dp/B004JU1WIG

https://doi.org/10.1093/acprof:oso/9780195393408.003.0012

Onyinah, O. 2006. God's Grace, Healing and Suffering. International Review of Mission 95, 576/377: 117 - 127.

Paret, P. \& S. Gleeson. 2016. Precarity and Agency through a Migration Lens.

Citizenship Studies 20,3-4:277 - 294.

https://doi.org/10.1080/13621025.2016.1158356 
Payne-Jackson, A. 2008. Spiritual Illness and Healing: 'If the Lord Wills'. In Mitchem, S. \& E.M. Townes (eds.): Faith, Health, and Healing in African American Life. Westport: Praeger Publishers.

https://www.amazon.com/Health-Healing-African-American-

Religion/dp/0275993752

Popoviciu, S., I. Popoviciu, D. Birle, S. Olah \& P. Negrut. 2013. The Role of

Religious Beliefs, Practices, and Metaphors in the Coping Strategies of Rare Disease Patients in Romania. In Stoltzfus, M.J., R. Green \& D. Schumm (eds.): Chronic Illness, Spirituality, and Healing: Diverse Disciplinary, Religious, and Cultural Perspectives. New York: Palgrave Macmillan.

https://doi.org/10.1057/9781137348456_10 https://doi.org/10.1057/9781137348456.0015

Porterfield, A. 2005. Healing in the History of Christianity. Oxford: Oxford University Press.

https://doi.org/10.1093/acprof:oso/9780195157185.001.0001

Stoltzfus, M.J. \& R. Green 2013. Spirituality, Chronic Illness, and Healing: Concluding Remarks and Ongoing Inquiry. In Stoltzfus, M.J., R. Green, (eds.): Chronic Illness, Spirituality, and Healing: Diverse Disciplinary, Religious, and Cultural Perspectives. New York: Palgrave Macmillan. https://doi.org/10.1057/9781137348456_2

https://doi.org/10.1057/9781137348456 15

https://doi.org/10.1057/9781137348456.0020

Währisch-Oblau, C. 2001. God Can Make us Healthy Through and Through: On Prayers for the Sick and Healing: Experiences in Christian Churches in China and African Immigrant Congregations in Germany. International Review of Mission XC, 356/357:94 - 99.

Waite, L. 2009. A Place and Space for a Critical Geography of Precarity? Geography Compass 3,1:412 - 433.

https://doi.org/10.1111/j.1749-8198.2008.00184.x

Warrington, K. 2003. The Role of Jesus as Presented in the Healing Praxis and Teaching of British Pentecostalism: A Re-Examination. The Journal of the Society for Pentecostal Studies 25,1:66 - 92.

https://doi.org/10.1163/157007403765694420

Wuthnow, R. \& S. Offutt 2008. Transnational Religious Connections. Sociology of Religion 69, 2:209 - 232.

https://doi.org/10.1093/socrel/69.2.209 
Henrietta M. Nyamnjoh

Henrietta M. Nyamnjoh

Research Fellow

Environmental \& Geographical Sciences

University of Cape Town

hmambo@gmail.com 